\title{
Development and Validation of PLS Models for Quantification of Biodiesels Content from Waste Frying Oil in Diesel by HATR- MIR
}

\author{
Gontijo, L. C.;* Guimarães, E.; Mitsutake, H.; Santana, F. B.; Santos, D. \\ Q.; Borges Neto, W.
}

Rev. Virtual Quim., 2014, 6 (5), 1517-1528. Data de publicação na Web: 9 de outubro de 2014

http://www.uff.br/rvq

\section{Desenvolvimento e Validação de Modelo PLS para Quantificação do Teor de Biodiesel Proveniente de Óleo de Fritura em Diesel empregando HATR-MIR}

Resumo: Este trabalho apresenta o desenvolvimento e a validação de dois modelos PLS para quantificação de biodiesel metílico e biodiesel etílico provenientes de óleos de fritura em misturas com diesel empregando dados de espectroscopia no infravermelho médio. A exatidão dos modelos PLS mostraram excelente desempenho com baixos valores de RMSEC, RMSECV e RMSEP. Além disso, a exatidão foi comprovada pela avaliação da região de elipse de confiança. O método foi validado de acordo com as diretrizes internacionais e nacionais pela estimativa de figuras de mérito, tais como exatidão, precisão, linearidade, seletividade, sensibilidade analítica, limites de detecção e quantificação e erro sistemático. Uma excelente correlação foi observada entre os valores reais e previstos do conjunto de previsão $(R=0,9999)$ e os modelos não apresentaram erros sistemáticos conforme a norma ASTM E1655. Os modelos propostos utilizam uma única faixa espectral permitindo a determinação de biodiesel em mistura com diesel na faixa de concentração entre 1,00 e $30,00 \%(v / v)$, em ambos os modelos. Assim, as metodologias propostas foram validadas sem a necessidade de escolher faixas espectrais se comparado com as normas pertinentes que regulamentam a determinação do teor de biodiesel em mistura com diesel.

Palavras-chave: Biodiesel; óleo de fritura; espectroscopia no infravermelho; calibração multivariada; PLS; validação analítica.

\begin{abstract}
This study presents the development and validation of two PLS models for quantification of methyl and ethyl biodiesels from waste frying oils in diesel blends by mid-infrared spectroscopy. The accuracy of the PLS models showed excellent performance by presenting low values of RMSEC, RMSECV and RMSEP. The PLS models provided RMSEC of $0.07 \%(\mathrm{v} / \mathrm{v})$ and $0.04 \%(\mathrm{v} / \mathrm{v})$ for the models containing methyl and ethyl biodiesels, respectively; and RMSEP of $0.09 \%(\mathrm{v} / \mathrm{v})$ and $0.05 \%(\mathrm{v} / \mathrm{v})$. Addition to the parameters of error it was evaluated the accuracy by elliptical joint confidence region. The method was validated according to international and national guidelines by the estimation of figures of merit, such as accuracy, precision, linearity, selectivity, analytical sensitivity, limits of detection and quantification and systematic error. An excellent correlation was observed in prediction set $(R=$ 0.9999), and no systematic errors were present according to the ASTM E1655 standard. The proposed models for the entire spectral region allowed the determination of both methyl and ethyl biodiesels from waste frying oil in diesel using concentrations between 1.00 and $30.00 \%(\mathrm{v} / \mathrm{v})$. The proposed methodologies were validated and no need for selecting intervals if compared with relevant standards that regulate the determination of biodiesel blend levels in diesel.

Keywords: Biodiesel; waste frying oil; infrared spectroscopy; multivariate calibration; PLS; analytical validation.

* Universidade Federal de Uberlândia, Instituto de Química, Campus Santa Mônica, CEP 38408-100, Uberlândia-MG, Brasil.

Mquilucas10@gmail.com

DOI: $10.5935 / 1984-6835.20140098$
\end{abstract}




\title{
Development and Validation of PLS Models for Quantification of Biodiesels Content from Waste Frying Oil in Diesel by HATR- MIR
}

\author{
Lucas C. Gontijo, ${ }^{a}, b, *$ Eloiza Guimarães, ${ }^{a}$ Hery Mitsutake, ${ }^{a}$ Felipe B. de

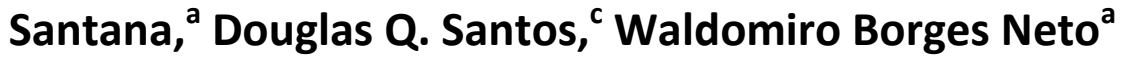 \\ a Universidade Federal de Uberlândia, Instituto de Química, Campus Santa Mônica, CEP 38408- \\ 100, Uberlândia-MG, Brasil.

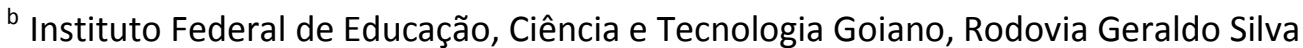 \\ Nascimento, km 2.5, CEP 75790-000, Urutaí-GO, Brasil. \\ ' Universidade Federal de Uberlândia, Escola Técnica de Saúde, Campus Umuarama; CEP \\ 38400-902, UberlândiaMG, Brasil. \\ *quilucas10@gmail.com
}

1. Introduction

\section{Experimental section}

2.1. Sample preparation

2.2. HATR-MIR spectra acquisition

2.3. Outlier detection

2.4. Chemometric analysis

2.5. Figures of merit

\section{Results and discussion}

\section{Conclusion}

\section{Introduction}

Biodiesel may be produced from different vegetable oils and animal fats. However, the costs of raw material and a limited availability of these vegetable oils can be a problem for biodiesel production. The costs of using vegetable oils to produce biodiesel can reach $75 \%$, resulting in a biodiesel production that is approximately 1.5 times greater than diesel oil. ${ }^{1}$ The problem of this high cost can be alleviated by using low cost raw materials such as waste frying oils. ${ }^{2,3}$ The conversion of this huge amount of waste frying oil into the fuel decreases the environmental impacts caused by the harmful disposal of these oils. Furthermore, it is possible to greatly reduce the total manufacturing costs since the price of waste frying oils is 2 to 3 times cheaper than virgin vegetable oils. ${ }^{4,5}$

Waste frying oils are generated in huge 
quantities after frying food in industrial environments, e.g., such as fast-food chains and restaurants. Thus, a substantial quantity of waste frying oil is generated every year. Currently, a very small percentage of these oils has been used in soap production. However, the soap produced from frying oil has poor quality, and the most part of waste frying oil goes down the sink, increasing ecological and economic problems. Thus, waste frying oil is a better alternative as a raw material for biodiesel production than other raw materials such as edible oil, nonedible oil and animal fats which are very costly and result in the high cost of biodiesel. ${ }^{6}$

In the literature, several studies were published upon the investigation of biodiesel production using frying oil through acidic or basic catalysis. ${ }^{2,4,7,8}$

Therefore, the biodiesel production from waste frying oil is a reality in the world. Because of this, the quantification of this type of biofuel mixed with diesel is essential, and the vibrational spectroscopy associated to multivariate analysis has been shown as a powerful tool to evaluate the biodiesel content in diesel. ${ }^{9-11}$ However, most of the papers quantify biodiesel by PLS and evaluate only one kind of biodiesel (methyl soybean biodiesel) and do not conduct a study of the validation of the respective analytical methods. Thus, when an analytical procedure is developed or there is a change in scope, it is necessary to validate the results to make the method reliable and suitable with the required quality. The standard that guides the validation of methods based on infrared spectroscopy is ASTM E1655 which refers to standard practices in quantitative analysis. ${ }^{12}$ However, in addition to the guidelines contained in the standard method other figures of merit (FOM) were calculated as linearity, adjustment, selectivity, analytical sensitivity, limits of detection and quantification. The main concept that has emerged in recent years for the calculation of figures of merit for multivariate calibration is the net analyte signal (NAS) that represents a breakthrough because it allows the separation of specific information of the analyte from the total signal. ${ }^{13-17}$

Therefore, the present study development and validated multivariate calibration models for quantification of methyl (FAME) and ethyl (FAEE) biodiesels from waste frying oil in diesel blends using the partial-least-squares (PLS) regression method and mid-infrared (MIR) spectroscopy verifying its adequacy with the requirements of the ABNT NBR 15568 standard. $^{18}$

\section{Experimental section}

\subsection{Sample preparation}

In this study, two partial-least-squares (PLS) regression models were proposed in order to determine biodiesel content from waste frying oil in diesel blends. The methyl (FAME) and ethyl (FAEE) biodiesels were provided by LABIO (Laboratory of Biofuels of the Institute of Chemistry) at the Federal University of Uberlândia, state of Minas Gerais, Brazil. To construct the model, 77 biodieseldiesel blends were prepared at concentrations ranging from 0.25 to $30.00 \%(\mathrm{v} / \mathrm{v})$. The pure diesel was provided by Transpetro S/A (Uberlândia, state of Minas Gerais, Brazil).

\subsection{HATR-MIR spectra acquisition}

The MIR spectra were acquired with a Perkin Elmer Spectrum Two spectrometer using the attenuated total reflectance (ATR) sample holder with a ZnSe crystal. The spectra were recorded in the range of 4000 to $600 \mathrm{~cm}^{-1}$ with a $4 \mathrm{~cm}^{-1}$ resolution and triplicates were acquired in 16 scans. The spectral baselines were corrected using baseline method in the range of 3150 to 4000 $\mathrm{cm}^{-1}$ and 1850 to $2500 \mathrm{~cm}^{-1}$. The initial data 
matrix was composed of 77 spectra with 2401 variables per spectrum.

\subsection{Outlier detection}

The outliers were detected by identifying samples with high leverage and residuals in the spectral data or high residuals in the analytical concentrations ${ }^{19}$ at a significance level of $5 \%$. The outliers were also detected by comparing high values of absolute errors in individual samples with the root-mean-squared errors of calibration (RMSEC). Thus, if the difference between the reference value and the estimated value of a sample was greater than three times the RMSEC, the sample was excluded. ${ }^{20}$

\subsection{Chemometric analysis}

The PLS models were built by using 49 samples in calibration set and 28 samples in prediction set. The data were mean-centered and the leave-one-out method was employed for the internal validation. The number of latent variables was selected according to the percentage of variance that was explained in $\mathbf{X}$ (absorbance) and $\mathbf{Y}$ (concentration) blocks on the joint comparison containing the plot of the root-mean-square error of crossvalidation (RMSECV). The PLS method were performed with Matlab 6.1 (Mathworks Inc.) software and PLS_Toolbox 3.5 (Eigenvector Research).

\subsection{Figures of merit}

The accuracy of the models were expressed as the root mean square error of calibration (RMSEC), root mean square error of cross-validation (RMSECV), and root mean square error of prediction (RMSEP), according to the Eq. $1 .{ }^{21}$ In addition, the better indicator including the consideration of the elliptical joint confidence region (EJCR) was performed. ${ }^{11}$

$$
R M S E=\sqrt{\frac{\sum_{i=1}^{n}\left(y_{i}-\hat{\mathrm{y}}_{i}\right)^{2}}{n}}
$$

Where $\hat{y}_{i}$ and $y_{i}$ are the model-estimated value and the reference value for sample $i$, respectively, and $n$ is the number of samples.

Precision was calculated foreseeing the calibration models in five concentration levels, as 5.00, 7.00, 10.00, 15.00 and $25.00 \%$ $(\mathrm{v} / \mathrm{v})$. Seven measurements were made for each level, as required by ASTM E1655. The standard deviation of the measurements was calculated using Eq. 2. ${ }^{12}$

$$
\sigma_{i}=\sqrt{\frac{\sum_{j=1}^{r_{i}}\left(\hat{\mathrm{y}}_{i j}-\overline{\mathrm{y}}_{i}\right)^{2}}{r_{i}-1}}
$$

Where, $\bar{y}_{i}$ is the mean value of the estimated values and $r_{i}$ is number of measurements per level. The relative standard deviation (RSD) was calculated by Eq. 3.

$$
R S D(\%)=\frac{\sum_{i=1}^{n} \frac{\sigma_{i}}{\bar{y}_{i}} \cdot 100}{p}
$$

Where, $p$ is the number of concentration levels evaluated.

Intermediate precision (RSDpi) was calculated by the standard deviation measurements of five concentration levels with seven replicates and three consecutive days, using Eq. $4 .{ }^{22}$ 


$$
\operatorname{RSpi}_{(i, k)}=\sqrt{\frac{1}{t\left(r_{i}-1\right)} \sum_{i=1}^{t} \sum_{k=1}^{r_{i}}\left(y_{i k}-\overline{\mathrm{y}}_{i}\right)^{2}}
$$

Where,

$t$ is the total number of tested samples;

$r_{i}$ is the number of measurements per level;

$y_{i k}$ is the result of $k$ value for the $i$ sample.

The fit of the PLS models was evaluated by correlating the real values with the predicted values from the prediction set. Furthermore, the linearity was used for a qualitative estimation of the model linearity through distribution of residuals versus the reference values.

Equation 5 was used to calculate the sensitivity (SÊN), in this work, where $\mathbf{b}$ is the vector of final regression coefficients, which can be obtained by any multivariate method. ${ }^{24,25}$

$$
\mathrm{SEN}=\frac{1}{\left\|\mathrm{~b}_{\mathrm{k}}\right\|}
$$

The analytical sensitivity $(\gamma)$, which is defined in analogy to univariate calibration, is calculated according to the Eq. 6. ${ }^{26,27}$

$$
\gamma=\frac{S \hat{\mathrm{E} N}}{\|\delta x\|}
$$

Where $\delta x$ is an estimate for the instrumental noise, through nine replicate spectra of the pure diesel.

The selectivity $\left(S \hat{E} L_{k, i}\right)$ was calculated using Eq. 7.24,25

$$
S \hat{\mathrm{E}} L_{k, i}=\frac{n \hat{\mathrm{a} s} s_{k, i}}{\left\|x_{k, i}\right\|}
$$

Where, $n a ̂ s_{k, i}$ is the scalar value of the net analyte signal for sample $i ; x_{k, i}$ is the vector of instrumental response for sample $i$.

The limits of detection and quantification were calculated analogously, as for univariate calibration, according to the Eq. 8 and Eq. 9, respectively. ${ }^{28}$

$$
\begin{gathered}
L D=3.3 \delta x \frac{1}{S \hat{\mathrm{E} N}} \\
L Q=10 \delta x \frac{1}{S \hat{\mathrm{E} N}}
\end{gathered}
$$

\section{Results and discussion}

The Figure 1 presents the mid-infrared spectra of biodiesel/diesel blends in concentrations from $0.25 \%$ to $30.00 \%(\mathrm{v} / \mathrm{v})$. The characteristic absorption bands of biodiesels occur in spectral regions of 1300 to $1000 \mathrm{~cm}^{-1}$ and 1750 to $1735 \mathrm{~cm}^{-1}$. These regions refer to the $\mathrm{C}-\mathrm{O}$ and $\mathrm{C}=\mathrm{O}$ bond stretching, respectively. ${ }^{18}$ Figure 1 a shows the spectrum after baseline correction employing baseline method. Moreover, the initial and final strips were removed due to noise signals and no response, respectively. Thus the range of the mid-infrared employed in the construction of the PLS models limited 3100 to $700 \mathrm{~cm}^{-1}$. 

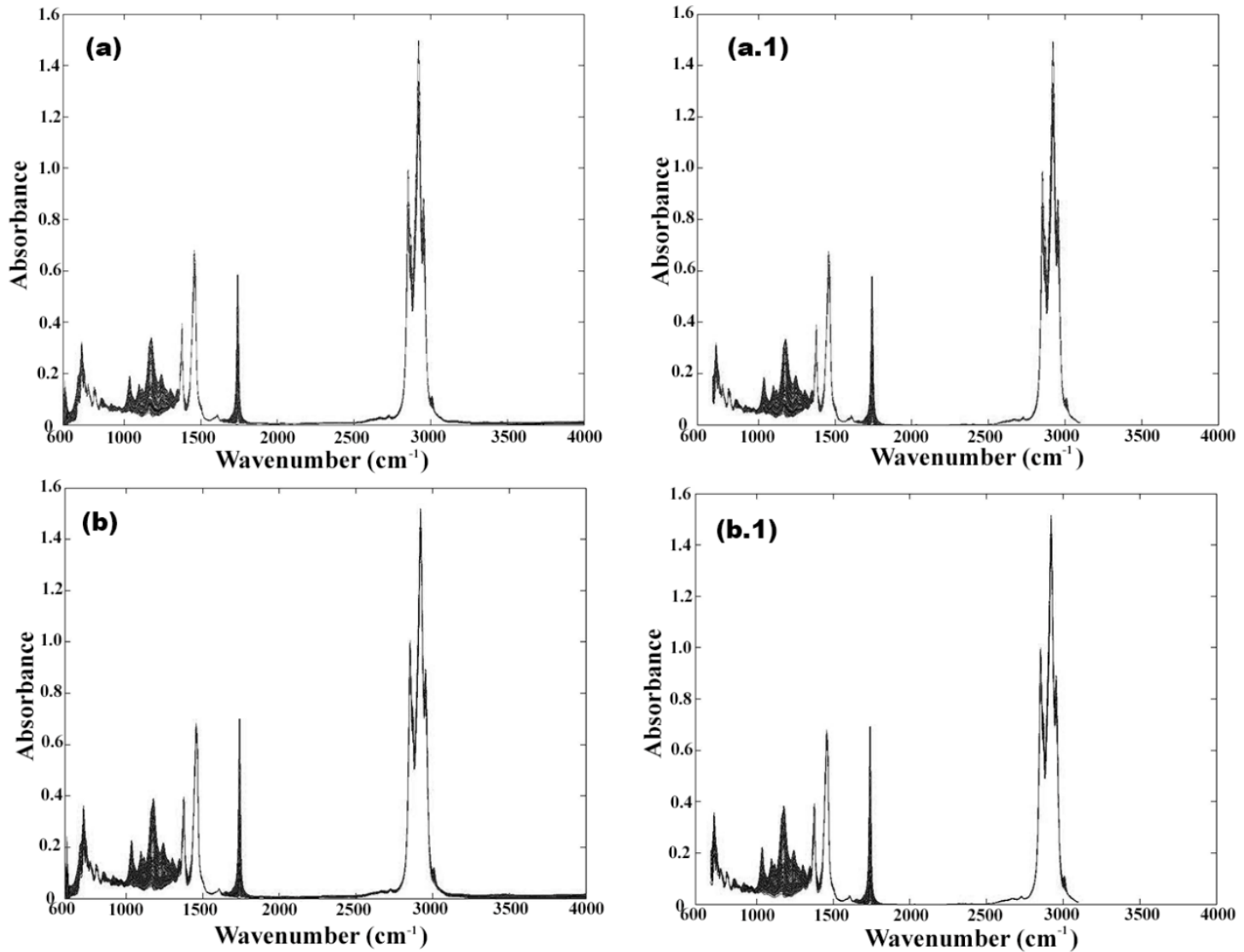

Figure 1. Mid-infrared spectra of samples of biodiesel blended with diesel in the concentration range from $0.25 \%$ to $30.00 \%(\mathrm{v} / \mathrm{v})$. (a) methyl biodiesel from waste frying oil; (b) ethyl biodiesel from waste frying oil; (a.1) and (b.1) the spectral baselines corrected by baseline method

An important step in the construction of multivariate calibration models is the identification of outliers that can affect the overall quality of the models. ${ }^{29}$ Figure 2 plots the $Q$ residuals versus the leverage. The horizontal lines represent the limits of studentized residuals at $95 \%$ confidence. The vertical line represents the critical influence of the leverage value, defined as $3 \mathrm{k} / \mathrm{n}$ in which $k$ is the number of factors and $n$ is the number of samples. ${ }^{30}$ Based on the plots, none of the samples was considered an outlier in the evaluated spectral region. However, outliers were detected from high absolute errors of the individual samples by comparing the RMSEC value. These outliers occurred in low concentration samples, limiting the useful range of the models between 1.00 and $30.00 \%(\mathrm{v} / \mathrm{v})$. 

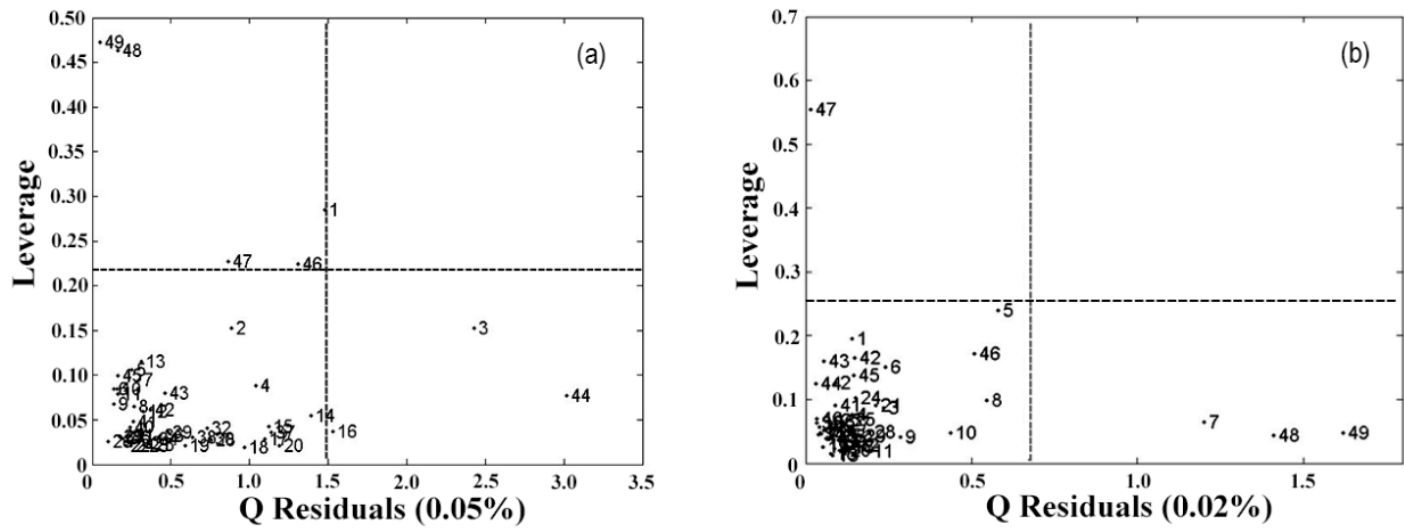

Figure 2. Plot of the spectral residuals versus the leverage at a significance level of $5 \%$ for (a) FAME and (b) FAEE from waste frying oil

The ASTM E1655 standard $^{12}$ establishes a minimum number of samples for constructing PLS models using infrared spectroscopy. Thus, the number of samples must equal $6(k+1)$ for mean-centered data in calibration set and $4 k$ in prediction set. The $k$ values correspond to the number of latent variables selected in the model. The PLS models were build with four latent variables. The number of variables in the model containing methyl biodiesel was chosen due to the lower RMSECV, which explained 99.96\% of the variance in $\mathbf{X}$ and $99.99 \%$ in $\mathbf{Y}$. To determine the ethyl biodiesel content, the explained variance values were $99.99 \%$ in $\mathbf{X}$ and $100 \%$ in $Y$. Therefore, the number of samples in calibration and prediction sets (Table 1) complies with the ASTM E1655 standard requeriments. ${ }^{12}$

Table 1. Root-mean-square errors of calibration, cross-validation and prediction for the PLS models of FAME and FAEE blended with diesel both with and without outlier detection

\begin{tabular}{ccccc}
\hline PLS models & \multicolumn{2}{c}{ FAME } & \multicolumn{2}{c}{ FAEE } \\
\hline Number of calibration samples & 49 & $45^{*}$ & 49 & $45^{*}$ \\
Number of prediction samples & 28 & 28 & 28 & 28 \\
RMSECV (\% v/v) & 0.12 & 0.09 & 0.05 & 0.05 \\
RMSEC (\% v/v) & 0.10 & 0.07 & 0.04 & 0.04 \\
RMSEP $(\% \mathrm{v} / \mathrm{v})$ & 0.12 & 0.09 & 0.06 & 0.05 \\
\hline
\end{tabular}

* after removal of outliers samples

The Brazilian method ${ }^{18}$ uses separating analytical models for ranges between $0-8 \%$ $(\mathrm{v} / \mathrm{v})$ and of $8-30 \%(\mathrm{v} / \mathrm{v})$ biodiesel. These models must also have RMSEP below $0.1 \%$ $(\mathrm{v} / \mathrm{v})$ and $1 \%(\mathrm{v} / \mathrm{v})$ for the aforementioned ranges, respectively. By comparing the build models with the requirements of the ABNT NBR 15568 standard, the models show RMSEP values below $0.10 \%$ for the range between 1.00 and $30.00 \%(\mathrm{v} / \mathrm{v})$. Thus, the proposed models are capable of determining biodiesel in a diesel blend using a single concentration range instead of two as proposed by the Brazilian standard. In addition, due to the future Brazilian requirement for the addition of $10 \%(\mathrm{v} / \mathrm{v})$ biodiesel into diesel, the ABNT NBR 15568 allows an accuracy of up to $1 \%$ for that biodiesel content. Therefore, the accuracy of the PLS models proposed follows the requirements of this standard. Figure 3 shows the EJCR for the PLS results and 
showed there was no significant difference between the prepared concentration values and PLS predicted concentration values, and that there was no evidence of bias within the
95\% confidence level. Furthermore, the proposed models can be employed to determine both FAME and FAEE without requiring spectral region selection.
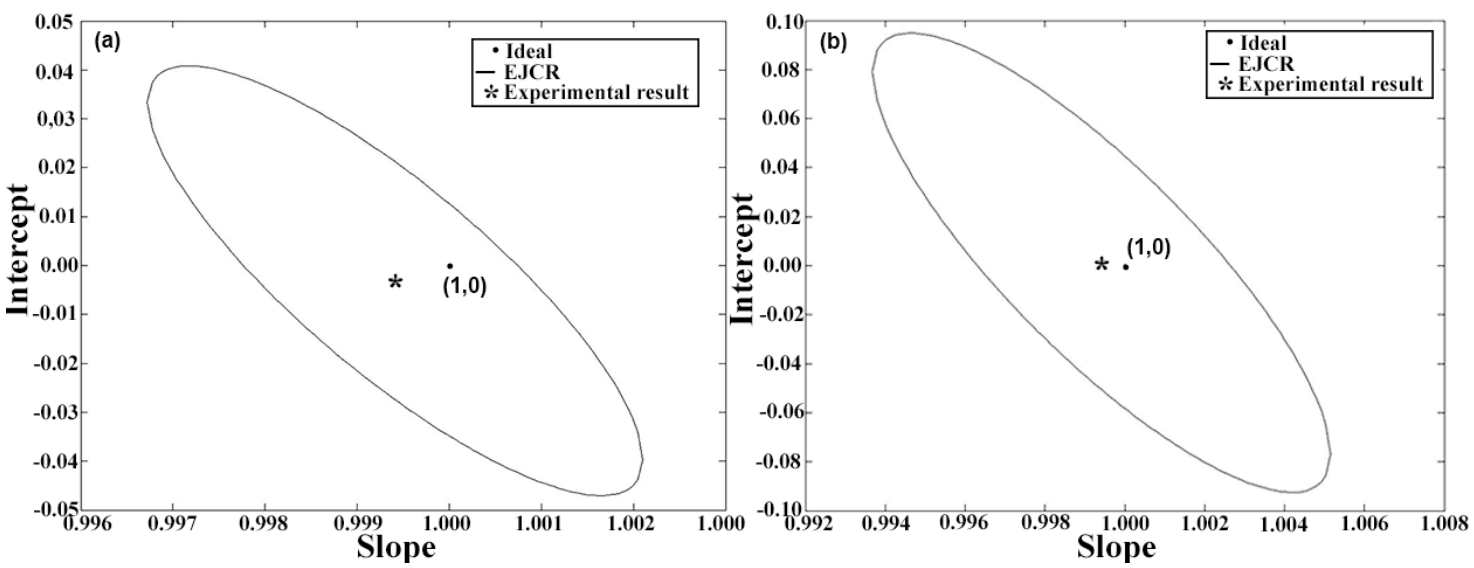

Figure 3. Elliptical joint confidence regions for the intercept and slope corresponding to regressions of measured concentration values versus PLS model predicted concentration values (\% v/v) of the prediction set. (a) FAME and (b) FAEE from waste frying oil

The evaluation of the fit of the models was done by correlating the reference values and the values calculated by the models of the prediction set. The excellent correlation $(R=0.9999)$ was obtained in both models (Figure 4).
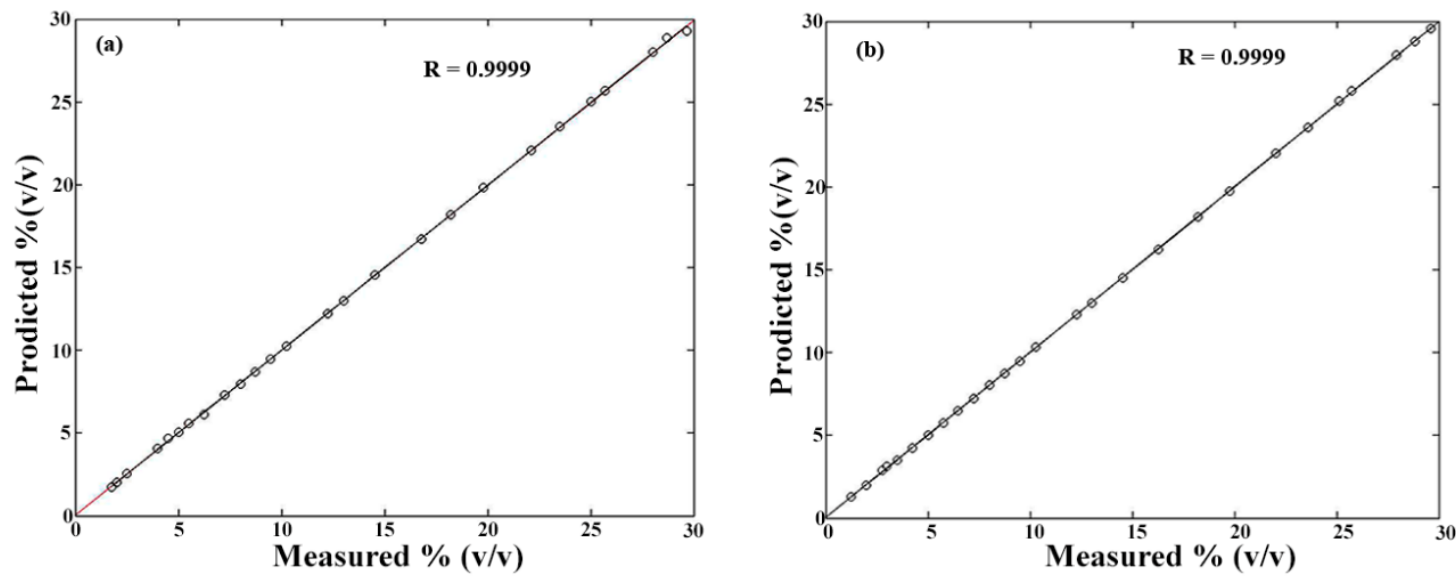

Figure 4. Fit of the PLS models through the real versus predicted values of the prediction set: (a) FAME and (b) FAEE from waste frying oil

The linearity of the models was determined using the PLS residuals, which in Figure 5 shows a random distribution of the errors evidencing the absence of systematic trends, as the models present a linear behaviour. 

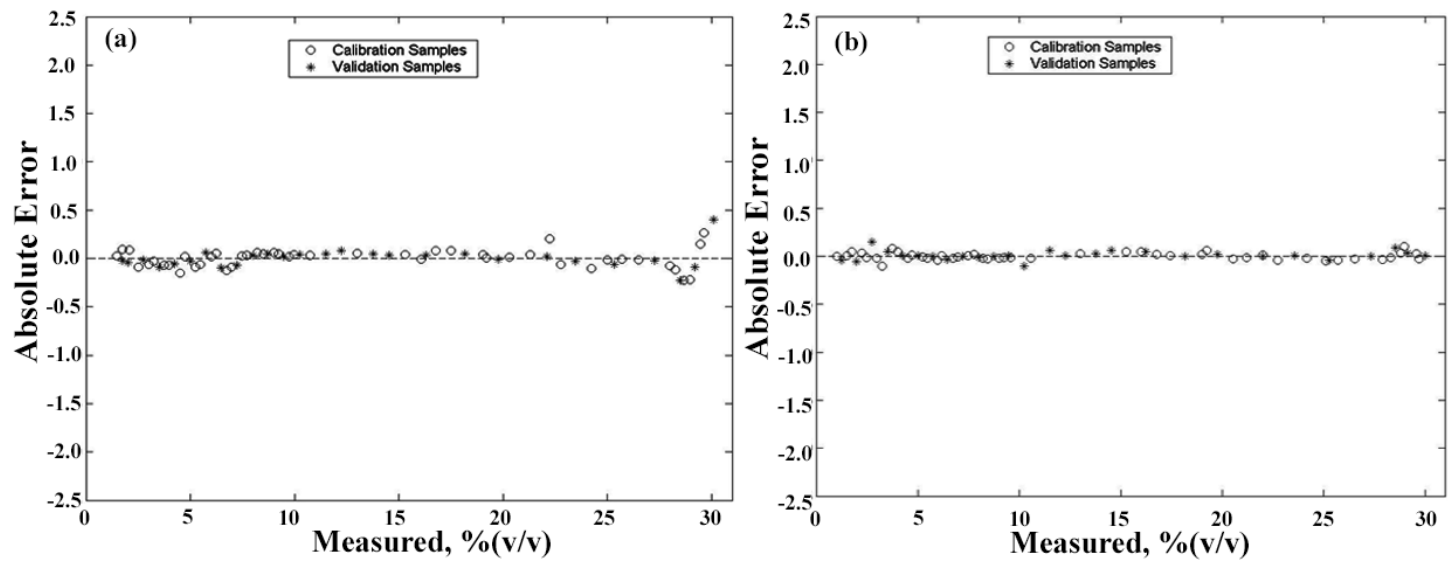

Figure 5. PLS residuals for the calibration and prediction set for the biodiesels from waste frying oil. (a) FAME biodiesel/diesel blend and (b) FAEE biodiesel/diesel blend

Table 2 shows the figures of merit estimated to validate the PLS models. The precision expresses the closeness of agreement between the results of a series of measurements for the same homogeneous sample under specified conditions. Analysing the RSD (Table 2) it is verified that it was satisfactory, i.e., less than $1 \%$ in both models. Regarding the RSD, intermediate precision values were close to $0.11 \%$. The limit of detection and the limit of quantification of the PLS models (Table 2 ) it was verified that the PLS models could detect amounts above $0.11 \%(v / v)$ of biodiesel in diesel, while for the quantification, the model could not determine values lower than $0.34 \%(v / v)$. As the concentration of biodiesel in the proposals PLS models ranging from $1.00 \%$ to $30.00 \%(\mathrm{v} / \mathrm{v})$, the models are effective to detect and quantify the biodiesels in diesel blends at concentrations higher than $0.34 \%$ $(\mathrm{v} / \mathrm{v})$.

Table 2. Parameters estimated for evaluating the main FOM of the PLS models

\begin{tabular}{cccc}
\hline Figures of merit & Parameter & \multicolumn{2}{c}{ Value } \\
\cline { 3 - 4 } & & FAME & FAEE \\
\hline Precision & RSD repeatability (\%) & 0.60 & 0.72 \\
& RSD intermediate precision (\%) & 0.10 & 0.10 \\
Limit of detection (\% v/v) & & 0.11 & 0.10 \\
Limit of quantification (\% v/v) & & 0.34 & 0.30 \\
Selectivity & & 0.10 & 0.03 \\
Sensitivity & & 0.08 & 0.09 \\
Analytical Sensitivity & & 29.14 & 32.80 \\
Inverse of analytical sensitivity & & 0.03 & 0.03 \\
Systematic error & bias & 0.001 & 0.023 \\
& Standard deviation & 0.104 & 0.048 \\
& Degree of freedom & 27 & 27 \\
& $\mathrm{t}_{\text {calc }}$ & 0.189 & 1.202 \\
& $\mathrm{t}_{\text {crit }}$ & 2.052 & 2.052 \\
\hline
\end{tabular}

The PLS models showed sensitivity in numeric values of $0.09 \%(\mathrm{v} / \mathrm{v})$. The inverse of the analytical sensitivity value, shown in Table 2, more clearly evaluated because of the direct relationship with the concentration. According to this value, the PLS models are able to distinguish differences among samples with concentration in the 
range of $0.03 \%(\mathrm{v} / \mathrm{v})$ for FAME biodiesel/diesel blends models. Regarding selectivity, the values found were 0.10 and 0.03 for FAME and FAEE biodiesel from waste frying oil in diesel blends models, respectively. However, this selectivity value does not refer to the selectivity in its physical meaning, which is generally used in analytical chemistry. It means that $10 \%$ of the signal was used for quantification because it does not contain interference.

\section{Conclusion}

The methodologies developed for quantification of biodiesels content from waste frying oil in diesel blends was validated in the concentrations ranging from 1.00 to $30.00 \%(\mathrm{v} / \mathrm{v})$. Thus, using mid-infrared combined with multivariate calibration and following the recommendations of the ASTM E1655 standard, the proposed models became simpler than proposed by the ABNT NBR 15568, in other words, the selection of specific spectral regions is unnecessary, which leads to a simplification and time reduction in both analysis and processing. Furthermore, the methodologies can be useful for fast, non-destructive and low cost monitoring of biofuel quality control with respect to quantification of biodiesel in diesel blends.

\section{Acknowledgement}

The authors would like to acknowledge FAPEMIG - Research Support Foundation of Minas Gerais, Project number FAPEMIG17.014/11 and the company Transpetro S/A for providing the fuel samples.

\section{References}

${ }^{1}$ Uzun, B. B.; Kılıç, M.; Özbay, N.; Pütün, A. E.; Pütün, E. Biodiesel production from waste frying oils: Optimization of reaction parameters and determination of fuel properties. Energy 2012, 44, 347. [CrossRef]

${ }^{2}$ Canakci, M. The potential of restaurant waste lipids as Biodiesel feedstocks. Bioresource Technology 2007, 98, 183. [CrossRef] [PubMed]

${ }^{3}$ Phan, A. N.; Phan, T. M. Biodiesel production from waste cooking oils. Fuel 2008, 87, 3490. [CrossRef]

${ }^{4}$ Encinar, J. M.; Gonzales, J. F.; RodriguezReinares, A. Ethanolysis of used frying oil. Biodiesel preparation and characterization. Fuel Processing Technology 2007, 88, 513. [CrossRef]

${ }^{5}$ Balat, M. Potential alternatives to edible oils for biodiesel production - A review of current work. Energy Conversion and Management 2011, 52, 1479. [CrossRef]

${ }^{6}$ Charpe, T. W.; Rathod, V. K. Biodiesel production using waste frying oil. Waste Management 2011, 31, 85. [CrossRef] [PubMed]

${ }^{7}$ Cayli, G.; Kusefoglu, S. Increased yields in biodiesel production from used cooking oils by a two step process: Comparison with one step process by using TGA. Fuel Processing Technology 2008, 89, 118. [CrossRef]

${ }^{8}$ Ozbay, N.; Oktar, N.; Tapan, N. A. Esterification of free fatty acids in waste cooking oils (WCO): Role of ion-exchange resins. Fuel 2008, 87, 1789. [CrossRef]

${ }^{9}$ Pimentel, M. F.; Ribeiro, G. M. G. S.; Cruz, R. S.; Stragevitch, L.; Pacheco Filho, J. G. A.; Teixeira, L. S. G. Determination of biodiesel content when blended with mineral diesel fuel using infrared spectroscopy and multivariate calibration. Microchemical Journal 2006, 82, 201. [CrossRef]

${ }^{10}{ }^{10}$ Ferrão, M. F.; Viera, M. S.; Pazos, R. E. P.; Fachini, D.; Gerbase, A. E.; Marder, L. Simultaneous determination of quality parameters of biodiesel/diesel blends using HATR-FTIR spectra and PLS, iPLS or siPLS regressions. Fuel 2011, 90, 701. [CrossRef] 
${ }^{11}$ Alves, J. C. L.; Poppi, R. J. Biodiesel content determination in diesel fuel blends using near infrared (NIR) spectroscopy and support vector machines (SVM). Talanta 2013, 104, 155. [CrossRef] [PubMed]

${ }^{12}$ ASTM Standard E1655. Standard practices for infrared multivariate quantitative analysis. ASTM International, West Conshohocken, PA, 2005. Available at < http://www.astm.org/>, (Acessed August 07, 2014).

${ }^{13}$ Sena, M. M.; Chaudhry, Z. F.; Collins, C. H.; Poppi, R. J. Direct determination of diclofenac in pharmaceutical formulations containing $B$ vitamins by ysing UV spectrophotometry and partial least squares regression. Journal of Pharmaceutical and Biomedical Analysis 2004, 36, 743. [CrossRef] [PubMed]

${ }^{14}$ Ferre, J.; Faber, N. M. Net analyte signal calculation for multivariate calibration. Chemometrics and Intelligent Laboratory Systems 2003, 69, 123. [CrossRef]

${ }^{15}$ Sarraguça, M. C.; Lopes, J. A. The use of net analyte signal (NAS) in near infrared spectroscopy pharmaceutical applications: Interpretability and figures of merit. Analytica Chimica Acta 2009, 642, 179. [CrossRef] [PubMed]

${ }^{16}$ Silva, M. A. M.; Ferreira, M. H.; Braga, J. W. B.; Sena, M. M. Development and analytical validation of a multivariate calibration method for determination of amoxicillin in suspension formulations by near infrared spectroscopy. Talanta 2012, 89, 342. [CrossRef] [PubMed]

${ }^{17}$ Inácio, M. R. C.; Lima, K. M. G.; Lopes, V. G.; Pessoa, J. D. C.; Teixeira, G. H. A. Total anthocyanin content determination in intact açaí (Euterpe oleracea Mart.) and palmiterojuçara (Euterpe edulis Mart.) fruit using near infrared spectroscopy (NIR) and multivariate calibration. Food Chemistry 2013, 136, 1160. [CrossRef] [PubMed]

${ }^{18}$ ABNT NBR. 15568 Brazilian Standard, 2008, Biodiesel: Determination of biodiesel content in diesel oil by mid-infrared spectroscopy, Brazilian Association of Technical Standards, Rio de Janeiro. Available at <www.abnt.org.br $>$, (Acessed August 07, 2014).

${ }^{19}$ Valderrama, P.; Braga, J. W. B.; Poppi, R. J. Variable selection, outlier detection, and figures of merit estimation in a partial leastsquares regression multivariate calibration model. A case study for the determination of quality parameters in the alcohol industry by near-infrared spectroscopy. Journal of Agricultural and Food Chemistry 2007, 55, 8331. [CrossRef] [PubMed]

${ }^{20}$ Ferreira, M. H.; Braga, J. W. B.; Sena, M. M. Development and validation of $a$ chemometric method for direct determination of hydrochlorothiazide in pharmaceutical samples by diffuse reflectance near infrared spectroscopy. Microchemical Journal 2013, 109, 158. [CrossRef]

${ }^{21}$ Vandeginste, B. G. M.; Massart, D. L.; Buydens, L. M. C.; Jong, S.; Lewi, P. J.; Smeyers-Verbeke, J. Handbook of Chemometrics and Qualimetrics: Part $B$, Elsevier: Amsterdam, 1998.

${ }^{22}$ National Institute of Metrology, Standardization and Industrial Quality (INMETRO); Guidelines on validation of chemical assays, DQO-CGRE-008, 2003. Available at < http://www.inmetro.gov.br>, (Acessed August 07, 2014).

${ }^{23}$ Pedro, A. M. K.; Ferreira, M. M. C. Nondestructive determination of solids and carotenoids in tomato products by nearinfrared spectroscopy and multivariate calibration. Analytical Chemistry 2005, 77, 2505. [CrossRef] [PubMed]

${ }^{24}$ Lorber, A.; Faber, K.; Kowalski, B. R. Net analyte signal calculation in multivariate calibration. Analytical Chemistry 1997, 69, 1620. [CrossRef]

${ }^{25}$ Ferre, J.; Brown, S. D.; Rius, F. X. Improved calculation of the net analyte signal in inverse multivariate calibration. Journal of Chemometrics 2001, 15, 537. [CrossRef]

${ }^{26}$ Boqué, R.; Faber, N. M.; Rius, F. X. Detection limits in classical multivariate calibration models. Analytica Chimica Acta 2000, 423, 41. [CrossRef]

${ }^{27}$ Laasonen, M.; Harmia-Pulkkinen, T.; Simard, C.; Rasanen, M.; Vuorela, H. Development and validation of a nearinfrared method for quantification of caffeine in intact single tables. Analytical Chemistry 2003, 75, 754. [CrossRef] [PubMed] 
${ }^{28}$ Boqué, R.; Rius, F. X. Multivariate detection limits estimators. Chemometrics and Intelligent Laboratory Systems 1996, 32, 11. [CrossRef]

${ }^{29}$ Fernandes, D. D. S.; Gomes, A. A.; Costa, G. B.; Silva, G. W. B.; Véras, G. Determination of biodiesel content in biodiesel/diesel blends using NIR and visible spectroscopy with variable selection. Talanta 2011, 87, 30. [CrossRef] [PubMed]
${ }^{30}$ Ferreira, M. M. C.; Antunes, A.M.; Melgo, M. S.; Volpe, P. L. O. Quimiometria I: Calibração Multivariada, um Tutorial. Química Nova 1999, 22, 724. [CrossRef]

${ }^{31}$ Rocha, W. F. C.; Nogueira, R; Vaz, B. G. Validation of model of multivariate calibration: an application to the determination of biodiesel blend levels in diesel by near-infrared spectroscopy. Journal of Chemometrics 2012, 26, 456. [CrossRef] 